\title{
Education as the path to a sustainable recovery from COVID-19
}

\author{
Radhika Iyengar ${ }^{1}$
}

Published online: 12 July 2020

(C) UNESCO IBE 2020

\begin{abstract}
COVID-19 has disrupted education for millions of children across the globe. The education community is re-imagining and re-designing to build back better. This Viewpoint takes the principles behind UNESCO's Futures of Education initiative to highlight their importance in post-COVID-19 recovery. The pandemic has shown how communities can come together to educate children. The article argues that, post-COVID-19, education systems should recognize community-driven support systems, use technology to overcome the digital divide in learning, and focus more on SDG 4.7 and its links to climate crises.
\end{abstract}

Keywords Sustainable development $\cdot$ SDG $4 \cdot$ Crisis $\cdot$ Community

Thanks to the COVID-19 pandemic, many children in developing countries, especially middle school girls, will probably never return to school. Even if health ministries flatten the COVID-19 death rate, we can expect the broader learning crisis to peak for many countries. However, many in the education community treat COVID-19 as an opportunity to build back better-to re-imagine and re-design education for the future. For example, at UNESCO's Futures of Education Commissioners meeting on June 19, 2020 (Juneteenth, a US holiday commemorating the end of slavery), global education leaders discussed the growing role of digital technology, how to reach the most vulnerable students, and how to design a meaningful curriculum for the future, one grounded in global citizenship and sustainable development. Sahle-Work Zewde, the visionary President of Ethiopia, co-presided over the meeting with UNESCO's Assistant Director-General for Education, Stefania Giannini. Their efforts give further evidence that good things are bound to emerge when women lead. The world would greatly benefit from more women leaders. The nine guiding

Radhika Iyengar

iyengar@ei.columbia.edu

1 Center for Sustainable Development, Earth Institute, Columbia University, 61 Claremont Avenue \#1040, New York, NY 10027, USA 
principles presented by the Commission on UNESCO Futures of Education formed the framework for the meeting. All the Commissioners agreed with these principles. In this Viewpoint I present several of these principles and some community-based practice examples, along with suggestions on how to move forward.

First, the Commissioners agreed that we have not utilized digital technology's full potential (Principle \#6, UNESCO 2020). The Digital Divide is real, but digital technologies can be a great unifier if there is universal access to connectivity and digital tools. All children must be ensured access to the digital world. Broadband connectivity must thus be made available to all schools, free of charge. UNESCO's ITU Broadband Commission must ramp up its efforts immediately to include all major technology companies in this project. The costs of coverage for schools must be slashed to enable universal coverage. Every village must have the electricity, the laptops, and the trained teachers to ensure that every child can connect to the world of online knowledge. This is not just the future we want; it is the present our children urgently need. With a big enough alliance, every school today can be reached.

That said, there is no education without human interaction (Principle \#3). Teachers have been the frontline workers for education even before this pandemic, so we need blended learning environments for education. Teachers need to interface with their students, even if they are assisted by TVs, smartphones, feature phones, laptops, and tablets. Google Classroom has developed a whole suite of integrated learning platforms that can be easily linked to YouTube, Lexia, Khan Academy, and other teaching aids. But each platform requires the teacher to create the right learning environment. This pandemic has taught us that each community has many experts who can teach. Traditional education, where knowledge is transferred from the school to the teacher to the student, is no longer useful. Instead, some community members have created virtual storytelling sessions, others have led online yoga sessions, and still others have formed environmental clubs on Zoom. Using community members for ongoing learning opportunities will help expand the subject matter scope, as well as make education more relevant for the children. The old style of developing a Parent Teacher Association-with little or no direction on how parents will help meet students' learning needs-needs to be transformed into a more dynamic and contextually relevant model. Let the communities directly help students to learn, rather than be kept at the periphery of schooling through fundraising, meal provision, and occasional volunteering. The school system should recognize that every parent is his or her child's first teacher.

The content of what the students learn is also a matter of great concern. This pandemic has opened our eyes to the lack of health education and physical education inside classrooms. Both students and adults need socio-emotional learning opportunities. Personal and social well-being activities must be integrated into the school curriculum at all levels: how else can we train future generations to be ethical and responsible citizens? Global citizenship needs to be translated from an abstract SDG (4.7) into activities and curricular resources for each class. Students need to know how to respect planetary boundaries and respect both people and cultures. Pope Francis, through his Global Compact on Education, is asking for precisely this (Bordoni 2020). Education for Sustainable Development (Principle \#7) should be given fair treatment, which includes teaching about environmental injustices, making sure that children and youth are connected with environmental action locally, and training them to raise their voices against social injustices (Principle \#9). In this direction, supported by UNESCO IBE, students, schoolteachers, youth, researchers, and academicians are coming together to define a roadmap that links SDG 4.7 and climate change. Their forthcoming book, titled "Charting an SDG 4.7 roadmap for radical, transformative change in the midst of climate breakdown", will identify new pathways to 
define global citizenship and its inter-linkages to climate breakdown (more information: https://www.edforsd.org/post/call-for-submissions). The pandemic has taught the world how we can all be empathetic and humane towards each other. From a health perspective, it has likewise taught us that our health depends on our neighbors' health. School curricula should reflect this interconnected nature of globalization.

Quality education needs substantial education financing. Poverty remains high, especially in the sub-Saharan region, with 41 percent of the population living on less than $\$ 1.90$ (USD) a day in 2015 (Gaspar et al. 2019). According to a recent IMF report, by 2030 the SDG agenda will require additional spending of $\$ 500$ billion for low-income developing countries and \$2.1 trillion for emerging market economies (Gaspar et al. 2019). With this pandemic, the global growth rate is expected to be $-3 \%$ (Gopinath 2020). UNESCO's (2015) costing models estimate an annual total cost of $\$ 340$ billion to achieve universal pre-primary, primary, and secondary education in low- and lower-middle-income countries by 2030 . The average annual per-student spending for quality primary education in a low-income country is predicted to be $\$ 197$ in 2030, creating an estimated annual gap of $\$ 39$ billion between 2015 and 2030. Financing this gap calls for action from private sector donors, philanthropists, and international financial institutions. Education needs more grant funding rather than loans (Sachs 2020). We cannot expect that developing countries will be able to repay loans on a social sector investment that does not yield dividends. Education is a public good. The international aid agencies and private foundations must support the governments to provide quality education to all (Principle \#1).

More immediately, we need to recover from the expected learning lags. Susan Dynarski, in a recent New York Times article, recommended giving recent graduates a stipend to tutor younger students this summer (Dynarski 2020). Mass tutoring, supported by the Federal Government, would ensure that, this summer, students could cope with the loss of learning. A year of learning from the field, as is present in Nigeria, could help connect youth with their communities and improve the learning curve for children of school-going age. Another organization, Pratham India Education Initiative, is reaching out to 12,000 villages through their village-based volunteers, who work with the village heads and other community members (Brid 2020). A phone call to the parents and simple text messages have helped to continue education in children's homes. These citizen-led education mechanisms embody Arnove's (2020) vision of creating Community Learning Centers. They would be an excellent way for the community to collectively help with student learning, whether through community libraries, church classes, or other such community-based mechanisms.

This pandemic period has been a stressful period: many children have lost their loved ones, and many parents have lost their jobs. When the schools reopen, let us make them a place to learn from each other and to support each other. Let us ask the children what they learned from their parents and community members in these months and let us make those ideas the foundation of their learning for the rest of the year.

\section{References}

Arnove, R. (2020). Imagining what education can be post-COVID-19. Prospects. https://doi.org/10.1007/ s11125-020-09474-1.

Bordoni, L. (2020, February 6). Vatican event paves the way to Global Compact on Education. Vatican News. https://www.vaticannews.va/en/vatican-city/news/2020-02/global-compact-education-vatican-seminar.html.

Brid, S. (2020). Conversations about education and COVID-19 in India. EcoAmbassadors workshop. https ://www.facebook.com/619150480/videos/10163648856305481/. 
Dynarski, S. (2020, May 7). The school year really ended in March. The New York Times. https://www. nytimes.com/2020/05/07/business/school-education-online-money.html.

Gaspar, V., Amaglobeli, M. D., Garcia-Escribano, M. M., Prady, D., \& Soto, M. (2019). Fiscal policy and development: Human, social, and physical investments for the SDGs. Washington, DC: International Monetary Fund (IMF).

Gopinath, G. (2020, April 14). The great lockdown: Worst economic downturn since the Great Depression. IMFBlog. Washington, DC: International Monetary Fund (IMF). https://blogs.imf.org/2020/04/14/thegreat-lockdown-worst-economic-downturn-since-the-great-depression/.

Sachs, J. (2020). Personal notes, Meeting of the Futures of Education Commissioners, 19 June 2020. Paris: UNESCO.

UNESCO (2015). Pricing the right to education: The cost of reaching new targets by 2030. Paris: UNESCO.

UNESCO (2020). Nine ideas for public action-New publication from the International Commission on the Futures of Education. Paris: UNESCO. https://en.unesco.org/futuresofeducation/news/nine-ideas-forpublic-action.

Publisher's Note Springer Nature remains neutral with regard to jurisdictional claims in published maps and institutional affiliations.

Radhika Iyengar is Director of Education and a Research Scholar at the Center for Sustainable Development of Columbia University's Earth Institute. She leads Education for Sustainable Development initiatives and promotes international education development as a practitioner, researcher, teacher, and manager. Her articles have been published in reputable journals and her reports are used by both domestic and international stakeholders. She received an MA in Economics from the Delhi School of Economics and a PhD from Teachers College, Columbia University. 